\title{
Correlates of constipation in people with Parkinson's
}

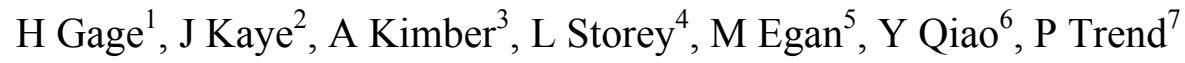

${ }^{1}$ Heather Gage (Corresponding author),

Dept. of Economics, University of Surrey, Guildford, Surrey, GU2 7XH, England

Telephone: 01483 686948; Fax: 01483 689548; Email: h.gage@surrey.ac.uk

${ }^{2}$ Julie Kaye, Parkinson's Disease Nurse Specialist, Surrey Primary Care Trust, Guildford

${ }^{3}$ Alan Kimber, School of Mathematics and Southampton Statistical Sciences Institute, University of Southampton

${ }^{4}$ Lesley Storey, School of Psychology, Queen's University, Belfast

${ }^{5}$ Bernadette Egan, Department of Psychology, University of Surrey, Guildford

${ }^{6}$ Yue Qiao, School of Economics, Shandong University, China

${ }^{7}$ Patrick Trend, Consultant Neurologist, Royal Surrey County Hospital NHS Trust, Guildford, Surrey

\section{Keywords:}

Parkinson's disease Constipation Correlates

Rome criterion Diet Exercise

Short title: Correlates of constipation in Parkinson's 


\begin{abstract}
Purpose: to investigate clinical, demographic and dietary factors associated with constipation in a sample of community dwelling people with Parkinson's disease, recruited through a specialist outpatient clinic. Partners / carers provided a convenience control group.
\end{abstract}

Scope: Participants completed a baseline questionnaire (background information, diet and exercise, activities of daily living: mobility and manual dexterity, health-related quality of life (SF-12), stool frequency and characteristics, extent of concern due to constipation, laxative taking), and a four week stool diary. The Rome criterion was used to determine constipation status. Multiple regression methods were use to explore the correlates of constipation. Baseline data were provided by 121 people with Parkinson's, (54 controls), of whom 73\% (25\%) met the Rome criterion. Prospective diary data from 106 people with Parkinson's (43 controls) showed lower proportions: $35 \%$ (7\%) meeting the Rome criterion. Constipation is predicted by having Parkinson's disease ( $\mathrm{p}=.003$; odds ratio $4.80,95 \%$ CI 1.64 to 14.04 ) and mobility score ( $\mathrm{p}=.04$; odds ratio $1.15,95 \%$ CI 1.01 to 1.31 ), but not by dietary factors. Amongst people with Parkinson's constipation is predicted by number of medications ( $\mathrm{p}=.027)$. Laxative taking masks constipation, and is significantly associated with wearing protection against bowel incontinence $(p=.009$; odds ratio $4.80,95 \%$ CI: 1.48 to 15.52$)$.

Conclusions: constipation is disease-related, not a lifestyle factor. More research is needed on optimal management and laxative use. 


\section{INTRODUCTION}

Constipation is common in older people [1]. It adversely affects quality of life [2], and incurs significant healthcare costs for laxatives and the treatment of complications. Constipation is a symptom of neurological disease [3,4] and studies show that $50 \%$ [5] to over 70\% [6] of people with Parkinson's suffer from constipation; and the excess burden relative to age matched controls may be as high as $60 \%$ [7-10]. Laxatives are estimated to be taken by approaching $40 \%$ of people with Parkinson's $[6,10]$. Constipation is one of several autonomic system failures associated with Parkinson's [7-9,11-14]. Mamometric investigations show two causes: anorectal 'outlet' dysfunction, causing straining, and slow colonic transit, suggesting local / peripheral nervous system effects and CNS mechanisms underlie constipation $[4,5,14-17]$.

Diagnosing constipation is difficult because it means different things to different people $[3,14]$. Infrequent bowel movement in the absence of other symptoms (straining, hard / lumpy stools, feeling of obstruction or incomplete evacuation) may lie within the normal spectrum [18]. Constipation is assessed by objective means (for example, self report of frequency), subjectively (expressions of 'bothersomeness' or concern caused by it) or behaviour (laxative taking or other self help measures).

It is not known why only some people with Parkinson's experience constipation. Improved understanding of the risk factors will help ensure that health professionals implement evidence - based management strategies [12]. The aim of this study was to investigate clinical, demographic and dietary factors associated with constipation in a sample of community dwelling people with Parkinson's disease.

\section{METHODS}

\section{Recruitment and data collection}


Ethical approval was obtained from the local NHS ethics committee. All people with Parkinson's attending a specialist outpatient clinic (except new patients and those with a recorded diagnosis of dementia) were sent an information sheet about the study and a letter inviting them to take part. Where appropriate, a separate information sheet and invitation was enclosed for partners / carers, who were included in the study to provide a convenient control group, and one that shared food preparation arrangements. Those interested in participating contacted the research team, and attended an interview at their next clinic visit. Repeat invitations were mailed to non responders, but only after a 12 month delay, on ethical grounds. At the clinic interview (conducted in private), a researcher received consent (separately for patients and partner / carers). Partners were asked to self complete baseline questionnaires, whilst the researcher collected data from patients. The researcher then gave participants a four week stool diary, and explained how to complete it. Participants were phoned after two weeks to assess progress. Completed diaries were returned in prepaid envelopes.

The target recruitment was 100 people with Parkinson's, and record reviews suggested that about $80 \%$ of community dwelling patients would have a partner / carer who could be invited to join the control group. Sample size calculations suggested that if 100 people with Parkinson's were recruited, using a 5\% significance level, a comparison of patients with partner / carers (controls) will yield 80\% power against a medium sized standardised difference of 0.6 .

\section{Measurement of constipation}

The baseline questionnaire was used to collect retrospective self report information on participants' experiences of constipation including: the extent to which constipation was a cause for concern; frequency of bowel movements; use of prescribed and purchased over-the-counter laxatives; self help measures (increased fluid, fibre, fruit and vegetable intake, other dietary change, extra exercise); soiling and use of protection due to bowel incontinence (see Table 3). The first version of the Rome criterion (Rome I) was used to objectively assess whether a participant suffered from constipation. This internationally recognised standard asks subjects whether, for at least a quarter of the time during the last three months, they have: had to strain 
when opening their bowels; had lumpy / hard stools; had a sensation of incomplete evacuation; had less than three bowel movements per week. Constipation is present if the subject answers 'yes' to two or more of the four symptoms [19].

To avoid inaccuracies from poor recall, diaries are recommended for collection of data on bowel function [20]. A bowel diary was purposefully developed for the study. Records were arranged one week to a page, and participants were asked to note daily the date and time of each bowel movement, (zero if no bowel opening), and use of laxatives / home remedies. Further information was recorded for each bowel movement: minutes spent, whether they felt empty afterwards (yes/no), straining $(0=$ none, $1=$ mild, $2=$ moderate, $3=$ severe), stool consistency (referring to pictures on the Bristol Stool Form Chart [21], range 1, separate hard lumps, like nuts (difficult to pass) to 7, watery, no solid pieces, entirely liquid). A sample of 12 diaries was independently reviewed by six nurses and continence advisors who concluded that the data generated were reliable and complete, enabling appropriate clinical interpretations to be drawn. Diary data were analysed to assess whether the bowel activity recorded met the Rome criterion (see footnote to Table 5). Participant's constipation status reported retrospectively at baseline was compared with that recorded prospectively in the diary.

\section{Other variables}

Baseline questionnaires were used to collect data from patients and partner / carers on factors potentially associated with constipation: socio - demographic, economic characteristics; life style behaviours, including exercise, liquid, fruit / vegetable and fibre intake; activity of daily living (ADL) disability measure [22]; physical and mental functioning component summary scores (PCS and MCS) of SF - 12 [23], an internationally validated measure of health- related quality of life (Table 2). Clinical information for people with Parkinson's was extracted from medical notes by a Parkinson's specialist nurse: Hoehn and Yahr disease stage [24], number of comorbidities and prescribed medications; taking COMT inhibitors (yes/ no - because diarrhoea is a side effect); taking agonists or anticholinergics (yes/ no - because constipation is a side effect). 


\section{Statistical analysis}

Data were entered into SPSS version 14. Basic analyses were undertaken using ttests, Pearson's correlation, ANOVA and contingency table tests as appropriate. Correlates of constipation (socio- economic and demographic, lifestyle behaviours, ADL, Parkinson's status) were explored using multiple regression and multiple logistic regression, with the Rome criterion ( $>=2$ symptoms) from the background questionnaire as the dependent variable. Patient only analyses additionally included clinical features: disease stage, number of co-morbidities and medications, whether or not taking COMT inhibitors, agonists, anticholinergics, and the presence / absence of dementia and hypotension. Statistical significance was attained at $\mathrm{p}<.05$.

\section{RESULTS}

\section{Characteristics of samples}

A total of 238 people with Parkinson's and 188 partner /carers (controls) were invited to participate over a 2 year period $(2005-7)$. Consent and baseline information was obtained from 121 (50.8\%) people with Parkinson's and 54 (28.7\%) partners / carers. Of these, $106(87.6 \%)$ people with Parkinson's and 43 (79.6\%) carers returned stool diaries. Recruitment continued beyond the planned target of 100 people with Parkinson's to increase the size of the control group.

About one half of people with Parkinson's recruited were Hoehn and Yahr stage 2 and reported no other health conditions (Table 1). A higher proportion of people with Parkinson's than partner / carers were male; there were no significant differences between groups in other socio - demographic, economic variables (Table 2). People with Parkinson's reported relatively high levels of independence (mean of 2, i.e. able to do activity alone with a little effort, on each item of the ADL disability scale), but in comparison to controls, their mobility, manual dexterity and PCS scores were significantly worse. Partners / carers reported eating significantly more fruit and 
vegetables, but there were no differences between groups in other self reported behaviours (Table 2).

\section{TABLES 1 AND 2 GO HERE}

\section{Baseline reporting of constipation}

On each measure, people with Parkinson's were significantly more likely to report constipation than controls (Table 3). Measures of constipation were closely correlated (Table 4). Patients (controls) stating that constipation caused them a lot of concern were 8.26 (11.5) times more likely to be taking any laxative, and 14 (7.2) times more likely to be constipated according to the Rome criterion than people who stated they were not greatly concerned by constipation.

\section{TABLES 3 AND 4 GOES HERE}

\section{Bowel incontinence}

Nine percent of respondents with Parkinson's, 3.7\% of partner / carer controls, reported wearing protection against faecal incontinence (Table 3). This behaviour was significantly associated with taking any laxative $(\mathrm{p}=.009)$. Of the 13 people wearing protection, 8 (61.5\%) take laxatives, compared to 40 of $165(24.7 \%)$ of those not wearing protection. People taking a laxative are almost five times more likely to wear protection than those who do not take a laxative (odds ratio $4.80,95 \% \mathrm{CI}: 1.48$ to 15.52). This relationship persists even after allowing for Parkinson's status ( $p=.019$; odds ratio $4.25,95 \% \mathrm{CI}: 1.27$ to 14.29 ).

\section{Stool diary analysis}

People with Parkinson's were significantly more constipated than controls (Table 5). Lower proportions of people with Parkinson's and of partner / carers were defined as constipated (Rome criterion) in the diary analysis than in retrospective reporting at baseline ( $35 \%$ vs $73 \%, 7 \%$ vs $24.5 \%$ respectively). There was no difference in constipation status at baseline between the people who completed the stool diary and 
those who did not, nor between the characteristics of people whose constipation status changed between baseline and diary and the characteristics of those whose status did not (data not shown).

\section{TABLE 5 GOES HERE}

Diaries show laxatives (and home remedies such as fibre) were taken by $45,42.4 \%$ $(11,10.4 \%)$ of people with Parkinson's and 2, 4.6\% (0) of partner / carers at least once during the 28 day observation period. The mean number of days laxatives (home remedies) were taken was 10 (6). Eight patients who took home remedies also used laxatives. Twenty three (21.7\%) patients and 2 (4.7\%) partner / carers reported taking laxatives at least once per week. The equivalent rates at baseline were 35\% (11\%). Patients taking daily laxatives $(n=7)$ had the highest mean frequency of stools $(1.04$, range $0.9-2.3)$. Over half of patients $(n=61,57.5 \%)$ reported no laxative use in their diaries and a mean of 1.0 stools per day $(0.3-3.9)$. The lowest stool frequency was recorded by occasional (once or twice a week) laxative users $(0.73,0.5$ $-1.0)$.

\section{Correlates of constipation}

In multiple regression analysis, the only factors predictive of constipation were having Parkinson's disease $(\mathrm{p}=.003)$ and ADL mobility $(\mathrm{p}=.04)$. People with Parkinson's are nearly five times more likely to meet the Rome criterion than partner / carer controls (odds ratio 4.80, 95\% CI 1.64 to 14.04). An increase of one unit in ADL mobility score raises the odds of meeting the Rome criterion by 1.15 (95\% CI 1.01 to 1.31 ). When the two ADL variables are not in the model, only a diagnosis of Parkinson's disease is a significant predictor of constipation (odds ratio 9.38, 95\% CIs 3.91 to 22.52).

Stating that constipation has been a cause for concern over adult life is significantly associated with meeting the Rome criterion at baseline $(\mathrm{p}=.031)$, including when Parkinson's diagnosis is incorporated in the model $(\mathrm{p}=.048)$. Hence, patients and partners / carers reporting constipation at baseline are equally likely to have reported concern over constipation throughout their adult life. 
Amongst patients, a significant association exists between constipation and number of medications ( $p=.027$ ), the major effect coming from taking $>=4$ medications (odds ratio relative taking 0 or 1 medication $8.62,95 \%$ CI 1.60 to 46.45$)$. There is no evidence of any association between constipation and number of comorbidities, having hypotension, or taking COMT inhibitors, agonists or anticholergineric medications.

\section{DISCUSSION}

The study confirms higher levels of self reported constipation amongst people with Parkinson's than partner / carer controls. The excess burden (according to Rome I criterion) amongst patients, compared to partner / carer controls (48\% at baseline ( $73 \%$ vs $25 \%$ ), and $28 \%$ (35\% vs $7 \%$ ) stool diary) is comparable to other studies [710]. Retrospectively, respondents self report higher levels of constipation according to the objective Rome criterion than by subjective (cause of concern) and behavioural (use of laxatives or other self help measures) indicators. The lower level of constipation reported through prospective diary data contrasts with other research which suggests that diaries over estimate constipation by under reporting stool frequency [5]. In this study, the discrepancy may arise because the retrospective reporting at baseline used the validated Rome criterion, with a 3 month reference period, but the diary data was collected over four weeks (to avoid jeopardising data quality by increasing participant burden). Applying the Rome criterion to one month of data might be expected a priori to result in a lower observed frequency of constipation because less time has elapsed for constipation episodes to occur.

Data from the baseline questionnaire suggest that only ADL mobility and having a diagnosis of Parkinson's disease are significantly associated with constipation. The link between female gender and psychological morbidity and constipation identified by other researchers $[3,15,25]$ was not found. In the patient sample, the number of medications taken is an independent predictor of constipation. Anticholinergic medications are known to have a constipating side effect $(26,29,45)$, but may not have been significant in our study because relatively small numbers of patients were taking 
them. Unlike other studies, the evidence reported here failed to find an association between constipation in Parkinson's and the disease process severity, diet or activity $[4,7,12,26]$ and low fibre, fluid intake or lack of exercise $[5,14,16,17]$. This may be because the data collection was not sufficiently detailed, or 'doses' were inadequate $[2,27]$.

High proportions of people with Parkinson's report straining, a sign of anorectal dysfunction (53), but there is less evidence of low frequency, a sign of slow transit, possibly because it is masked by laxative taking. Only $13(12.3 \%)$ people with Parkinson's completing the diary show less than four bowel movements per week across the 28 days. Higher stool frequency is associated with taking more laxatives, and there is some evidence that this is linked to bowel incontinence. No evidence was found that having Parkinson's is associated with reporting constipation over adult life despite other studies suggesting that constipation is a preclinical indicator $[16,28,29]$.

The data used in the analysis are robust. Baseline questionnaires were administered by researchers in a clinic setting, and recognised objective measures of constipation (Rome I, and Bristol Stool Form Chart) were used. The stool diary was independently validated by a panel of experienced nurses. The four week reporting period allows sufficient time for usual patterns to be observed. Participants who completed diaries undertook the task seriously and recorded data meticulously such that missing observations were minimal.

The limitations of this study are that partner / carer recruitment fell short of expectations (47 vs 78). Many partners/ carers were not willing to take part, and this affected the statistical comparisons between groups. Other trials of constipation have also reported problems recruiting participants due to the sensitive nature of the subject [18]. The representativeness of people recruited to the study is not known. Gender imbalance in the sample (more women in the carer group than patient group) may affect the interpretation of the findings if constipation is not equally experienced by men and women. The patient sample covered all disease stages, although $50 \%$ were Hoehn and Yahr stage 2, and as a group, they reported relatively little disability in ADL. The most up-to-date version of the Rome criterion [30] was not used in the 
study because, in piloting, participants found the lengthened reference period (12 rather than three months) problematical.

This study suggests that constipation is disease related, rather than a life style issue. Constipation - related problems cause daily concern for significant numbers of people, and there is a need for further research into optimal management regimens, including robust trials to provide an evidence-base for practitioners. 


\section{ACKNOWLEDGEMENTS}

This work was supported in part by an Educational Grant from Norgine Ltd The authors are grateful to Professor Christine Norton for advice at the planning stage, Rose Neilson for contributing to data collection and Tom Bird for assistance with preparation of the manuscript. The study could not have been completed without the people with Parkinson's and partners / carers who willingly and meticulously completed the diaries, and we thank them sincerely for their contributions. The work was supported in part by an Educational Grant from Norgine Ltd. The authors take full responsibility for the content of the paper.

\section{AUTHOR ROLES}

Gage: conception and organisation of research and wrote first draft of manuscript; Kaye: conception, organisation and execution of research; Kimber: statistical analysis; Storey: conception, organisation and execution of research; Egan: execution of research; Qiao: execution of research; Trend; conception and execution of research. All authors reviewed and critiqued the manuscript. 


\section{REFERENCES}

[1]. Petticrew M, Watt I, Sheldon T. A systematic review of the effectiveness of laxatives in the elderly. Health Technol Assess 1997; 1: 1-52.

$\{2\}$. Annells M, Koch T. Constipation and the preached trio: diet, fluid intake, exercise. Int J Nurs Stud 2003; 40: 843-52.

[3]. Kamm MA. Constipation and its management. Brit Med J 2003; 327: 459-60.

[4]. Bassotti G, De Gorgio R, Stangliellini V, Tonini M, Barbara G, Salvioli B, et al. Constipation: a common problem in patients with neurological abnormalities. Ital J Gastroenterol 1998; 30: 542-8.

[5]. Ashraf W, Pfeiffer RF, Park F, Lef J, Quigley EM. Constipation in Parkinson's disease: objective assessment and response to psyllium. Movement Disord 1997; 12: 946-51.

[6]. Bassotti G, Maggio D, Battaglia E, Giulietti O, Spinotti F, Reboldi G, et al. Manometric investigation of anorectal function in early and late stage Parkinson's disease. J Neurol Neurosur Ps 2000; 68: 768-70.

[7]. Edwards LL, Pfeiffer RF, Quigley EMM, Hofman R, Balluff M. Gastrointestinal symptoms in Parkinson's disease. Movement Disord 1991; 6: 151-56.

[8]. Sakakibara R, Shinotch H, Uchiyama T, Sakuma M, Kashiwado M, Yoshiyama $\mathrm{M}$, et al. Questionnaire-based assessment of pelvic organ dysfunction in Parkinson's disease. Auton Neurosci 2001; 92: 76-85.

[9]. Singer C, Weiner W, Sanchez-Ramos JR. Autonomic Dysfunction in Men with Parkinson's Disease. Eur Neurol 1992; 32: 134-140.

[10]. Kaye J, Gage H, Kimber A, Storey L, Trend P. Excess burden of constipation in Parkinson's Disease: A Pilot Study. Movement Disord 2006; 21: 1270-3.

[11]. Adler H. Non motor complications in Parkinson's disease. Movement Disord 2005; 20 (suppl. 11): 523-529.

[12]. Edwards LL, Quigley EMM, Hofman R, Pfeiffer RF. Gastrointestinal symptoms in Parkinson's disease: 18 month follow-up study. Movement Disord 1993; 8: 83-86.

[13]. Jost W. Gastrointestinal motility problems in patients with Parkinson's disease. Effects of anti parkinsonian treatment and guidelines for management. Drugs Aging 1997; 10: 249-58.

[14]. Pfeiffer RF, Quigley M. Gastrointestinal mobility problems in patients with Parkinson's disease. Epidemiology, Pathophysiology and Guidelines for Management. CNS Drugs 1999; 11: 435-48. 
[15]. Quigley EM. Gastrointestinal dysfunction in Parkinson's disease. Semin Neurol 1996; 16: 245-249.

[16]. Ueki A, Otsuka M. Life style issues of Parkinson's disease: association between decreased water intake and constipation. J Neurol 2004; 251 (Suppl. 7): 18-23.

[17]. Astarloa R, Mena M, Sanchez V, De La Vega L, De Yebenes JG. Clinical and Pharmacokinetic effects of a diet rich in insoluble fibre on Parkinson's disease. Clin Neuropharmacol 1992; 15: 375-80.

[18]. Mihaylov S, Stark C, McColl E, Steen N, Vanoli A, Rubin G, et al. Stepped treatment of older adults on laxatives: The STOOL trial. Health Technol Assess 2008; 12: ix-139.

[19]. Thompson WG, Cread F, Drossman DA, Heaton KW, Mazzacca G. Functional bowel disease and functional abdominal pain. Gastroenterol 1992; 5: 75-91.

[20]. Norton C, Chelvanayagam S. Bowel Continence Nursing. Beaconsfield: Beaconsfield Publishers; 2004.

[21]. Heaton KW. Bristol Stool Form Chart, Reader in Medicine, University of Bristol.

[22]. Brown RG, MacCarthy B, Jahanashahi M, Marsden C. Accuracy of self reported disability in patients with Parkinsonism. Arch Neurol 1989; 46: 95-99

[23]. Ware JE, Kosinski M, Keller SD. A 12 item short form health survey: construction of scales and preliminary tests or reliability and validity. Med Care 1996; $34 ; 220-23$

[24]. Hoehn MM, Yahr MD. Parkinsonism: onset, progression and mortality. Neurology 1967; 17: 427-42.

[25]. Stark ME. Challenging problems presenting as constipation. Am J Gastroenterol 1999; 84: 567-74.

[26]. Krogh K, Christensen P, Laurberg S. Colorectal symptoms in patients with neurological disease. Acta Neurol Scand 2001; 103: 335-43.

[27]. Meshkinpour H, Selod S, Movahedi H, Nami N, James N, Wilson A. Effects of Regular Exercise in Management of Chronic Idiopathic Constipation. Digest Dis Sci 1998; 43: 2379-83.

[28]. Abbott R, Petrovitch H, White L, Masaki K, Tanner C, Curb J, Grandinetti A, Blanchette P, Popper J, Ross G. Frequency of bowel movements and the future risk of Parkinson's disease. Neurology 2001; 57: 456-62.

[29]. Abbott RD, Ross GW, Petrovitch H, Tanner CM, Davis DG, Masaki KH, Launer LJ, Curb JD, White LR. Bowel movement frequency in later life and incidental Lewy bodies. Movement Disord 2007; 22: 1581-86. 
[30]. Thompson WG, Longstreth GF, Drossman DA, Heaton KW, Irvine EJ, MullerLissner SA. Functional bowel disorders and functional abdominal pain. Gut 1999; 45(Suppl 2): 1143-47. 
TABLE 1: Clinical characteristics of participants with Parkinson's disease*

\begin{tabular}{|c|c|c|c|c|}
\hline Characteristic & $\mathbf{n}$ & Values & Frequency & $\%$ \\
\hline \multirow{4}{*}{$\begin{array}{l}\text { Hoehn and Yahr disease } \\
\text { stage }\end{array}$} & \multirow[t]{4}{*}{106} & Stage 1 & 5 & 4.7 \\
\hline & & Stage 2 & 53 & 50.0 \\
\hline & & Stage 3 & 44 & 41.5 \\
\hline & & \begin{tabular}{|l|} 
Stage 4 \\
\end{tabular} & 4 & 3.8 \\
\hline \multirow{5}{*}{$\begin{array}{l}\text { Number of comorbidites } \\
\text { Mean } 0.93 \\
\text { Standard Deviation } 1.14\end{array}$} & \multirow[t]{5}{*}{108} & None & 53 & 49.1 \\
\hline & & 1 & 25 & 23.2 \\
\hline & & 2 & 20 & 18.5 \\
\hline & & 3 & 6 & 5.6 \\
\hline & & 4 or more & 4 & 3.7 \\
\hline \multirow{6}{*}{$\begin{array}{l}\text { Number of medications } \\
\text { Mean } 2.76 \\
\text { Standard Deviation } 1.72\end{array}$} & \multirow[t]{6}{*}{108} & None & 5 & 4.6 \\
\hline & & 1 & 16 & 14.8 \\
\hline & & 2 & 34 & 31.5 \\
\hline & & 3 & 27 & 24.5 \\
\hline & & 4 & 15 & 13.9 \\
\hline & & 5 or more & 11 & 10.3 \\
\hline Takes COMT inhibitor & 108 & Yes & 8 & 7.4 \\
\hline Takes dopamine agonist & 108 & Yes & 71 & 65.7 \\
\hline Takes anticholinergic & 108 & Yes & 5 & 4.6 \\
\hline
\end{tabular}

* Clinical data were available from the medical notes of 108 of the 121 people with Parkinson's who consented to participate in the study (89.3\%) 
TABLE 2: Socio - demographic, economic, diet, activity and health related quality of life: comparison of people with Parkinson's and partners / carers (controls)

\begin{tabular}{|c|c|c|c|c|c|c|}
\hline \multirow[t]{2}{*}{ Item } & \multirow[t]{2}{*}{ Responses } & \multicolumn{2}{|c|}{$\begin{array}{c}\text { People with } \\
\text { Parkinson's (PwP) } \\
\text { n=121* }\end{array}$} & \multicolumn{2}{|c|}{$\begin{array}{c}\text { Partners /Carers } \\
\text { (Controls) } \\
\mathbf{n}=\mathbf{5 4} \%\end{array}$} & \multirow{2}{*}{$\begin{array}{l}\text { Significant } \\
\text { difference } \\
\text { PwP vs } \\
\text { Controls } \\
\end{array}$} \\
\hline & & $\mathbf{n}$ & $\%$ & $\mathbf{n}$ & $\%$ & \\
\hline Gender & Male & 73 & 60.3 & 18 & 33.3 & $\mathrm{p}=.001$ \\
\hline Mean age $(\mathrm{n}=52$ carers $)$ & In years & 69.8 & $\mathrm{SD}=8.5$ & 68.1 & $\mathrm{SD}=9.9$ & $\mathrm{p}=.342$ \\
\hline \multirow{4}{*}{$\begin{array}{l}\text { Highest level of } \\
\text { education }\end{array}$} & Below age $15 / 16$ & 51 & 42.8 & 19 & 35.2 & \multirow{4}{*}{$\begin{array}{l}<=18 \text { vs }>18 \\
p=.992\end{array}$} \\
\hline & Age 17/18 & 13 & 10.9 & 10 & 18.5 & \\
\hline & College & 36 & 30.3 & 19 & 35.2 & \\
\hline & University & 19 & 16.0 & 5 & 9.3 & \\
\hline \multirow[t]{4}{*}{ Employment status } & Full time & 8 & 6.6 & 3 & 5.6 & \multirow{4}{*}{$\begin{array}{l}\text { Employed vs } \\
\text { not employed } \\
\mathrm{p}=.942\end{array}$} \\
\hline & Part time & 5 & 4.1 & 3 & 5.6 & \\
\hline & Retired & 106 & 87.6 & 46 & 85.2 & \\
\hline & Other & 2 & 1.7 & 2 & 3.8 & \\
\hline \multirow{4}{*}{$\begin{array}{l}\text { Household net annual } \\
\text { income } \\
\text { ( } \mathrm{n}=100 \text { PwP, } \\
\mathrm{n}=43 \text { carers) }\end{array}$} & $<£ 10,000$ & 18 & 18.0 & 7 & 16.3 & \multirow[t]{4}{*}{$\mathrm{p}=.599$} \\
\hline & $£ 10,000-19,999$ & 41 & 41.0 & 17 & 39.5 & \\
\hline & $£ 20,000-20,999$ & 20 & 20.0 & 10 & 23.2 & \\
\hline & $>=£ 30,000$ & 21 & 21.0 & 9 & 20.9 & \\
\hline \multirow{2}{*}{$\begin{array}{l}\text { ADL disability scale\# } \\
(\mathrm{n}=120,113 \text { PwP, } \\
\mathrm{n}=51,46 \text { carers }) \\
\text { High is worse }\end{array}$} & $\begin{array}{l}8 \text { item Mobility } \\
\text { (range } 8-40 \text { ) }\end{array}$ & $\begin{array}{c}\text { Mean } \\
15.6 \\
\end{array}$ & $\mathrm{SD}=5.9$ & $\begin{array}{c}\text { Mean } \\
9.5 \\
\end{array}$ & $\mathrm{SD}=3.1$ & $\mathrm{p}<.001$ \\
\hline & $\begin{array}{l}14 \text { item Manual } \\
\text { dexterity }(14-70)\end{array}$ & $\begin{array}{c}\text { Mean } \\
27.7 \\
\end{array}$ & $\mathrm{SD}=9.9$ & $\begin{array}{c}\text { Mean } \\
14.8 \\
\end{array}$ & $\mathrm{SD}=1.7$ & $\mathrm{p}<.001$ \\
\hline \multirow{2}{*}{$\begin{array}{l}\text { HRQoL:SF-12 } \\
(\mathrm{n}=52 \text { carers }) \\
\text { Worst } 0-100 \text { Best }\end{array}$} & PCS mean & 35.9 & $\mathrm{SD}=11.3$ & 45.7 & $\mathrm{SD}=9.8$ & $\mathrm{p}<.001$ \\
\hline & MCS mean & 43.3 & 10.0 & 44.5 & 9.5 & $\mathrm{p}=.442$ \\
\hline \multirow{6}{*}{$\begin{array}{l}\text { How often do you } \\
\text { exercise per day, not } \\
\text { including normal } \\
\text { duties? }\end{array}$} & Every day & 58 & 47.9 & 18 & 33.3 & \multirow{6}{*}{$\begin{array}{l}>=\text { once per } \\
\text { week vs } \\
<\text { once per } \\
\text { week } \\
\mathrm{p}=.839\end{array}$} \\
\hline & $2-3$ times per week & 22 & 18.2 & 19 & 35.2 & \\
\hline & About once a week & 17 & 14.1 & 7 & 13.0 & \\
\hline & 1-2 times / month & 2 & 1.7 & 0 & 0 & \\
\hline & Rarely, never & 20 & 16.5 & 9 & 16.7 & \\
\hline & Don't know & 2 & 1.7 & 2 & 4.6 & \\
\hline \multirow{5}{*}{$\begin{array}{l}\text { Type of exercise } \\
\text { ( } \mathrm{n}=97 \text { PwP, } n=43 \\
\text { carers). Other: bowling, } \\
\text { gym, weights, tennis, } \\
\text { gardening,cycling, golf, } \\
\text { aerobics, exercise bike. }\end{array}$} & Walking & 52 & 53.6 & 31 & 72.1 & \multirow{5}{*}{$\begin{array}{l}\text { Walking } \mathrm{v} \text { rest } \\
\mathrm{p}=.060\end{array}$} \\
\hline & Swimming & 3 & 3.1 & 1 & 2.3 & \\
\hline & Stretch / yoga & 6 & 6.2 & 0 & 0 & \\
\hline & Physiotherapy & 14 & 14.4 & 1 & 2.3 & \\
\hline & Other & 22 & 22.7 & 10 & 23.3 & \\
\hline \multirow[t]{3}{*}{ Cups of liquid per day } & $0-4($ score 1$)$ & 24 & 19.8 & 5 & 9.3 & \multirow{3}{*}{$\begin{array}{l}0-8 \text { vs }>=9 \\
p=.179\end{array}$} \\
\hline & $5-8$ (score 2$)$ & 74 & 61.2 & 35 & 64.8 & \\
\hline & $>=9($ score 3$)$ & 23 & 19.0 & 14 & 25.9 & \\
\hline \multirow{4}{*}{$\begin{array}{l}\text { Portions of fruit and } \\
\text { vegetables per day } \\
(n=53 \text { carers })\end{array}$} & 0 (score 1$)$ & 2 & 1.7 & 0 & 0 & \multirow{4}{*}{$\begin{array}{l}0-2 \text { vs }>2 \\
p=.163\end{array}$} \\
\hline & $1-2($ score 1$)$ & 25 & 20.7 & 7 & 13.2 & \\
\hline & $3-4($ score 2$)$ & 51 & 42.2 & 21 & 39.6 & \\
\hline & $>=5($ score 3$)$ & 43 & 35.5 & 25 & 47.2 & \\
\hline \multirow[t]{3}{*}{$\begin{array}{l}\text { Choose high fibre bread } \\
(n=120 \text { PwP) }\end{array}$} & $\begin{array}{l}\text { Always/usually } \\
\text { (score 3) }\end{array}$ & 72 & 60.0 & 37 & 68.5 & \multirow{3}{*}{$\begin{array}{l}\text { Always/ } \\
\text { usually vs rest } \\
\mathrm{p}=.283\end{array}$} \\
\hline & Sometimes (score 2) & 37 & 30.1 & 14 & 26.0 & \\
\hline & Never (scores 1) & 11 & 9.2 & 3 & 5.5 & \\
\hline $\begin{array}{l}\text { 'Bowel friendly diet' } \\
\text { score: }(n=120 \text { PwP, } \\
n=53 \text { carers }) .\end{array}$ & $\begin{array}{l}\text { Score from sum of } 3 \\
\text { diet variables above } \\
\text { (Range: } 3-9)\end{array}$ & $\begin{array}{c}\text { Mean } \\
6.48\end{array}$ & $\mathrm{SD}=1.38$ & $\begin{array}{c}\text { Mean } \\
7.11\end{array}$ & $\mathrm{SD}=1.20$ & $\mathrm{p}=.003$ \\
\hline
\end{tabular}

Key: * Missing observations for some variables; SD: Standard Deviation;

ADL: Activities of Daily Living Disability (45), 25 items measured on a 5 point scale across 2 dimensions (Mobility and Dexterity): $1=$ able to do it alone without difficulty to $5=$ unable to do it at all. Items relating to use of public transport and getting in and out of the bath were not applicable to many respondents and removed from the analysis. HRQoL: Health Related Quality of Life from SF-12 (46); PCS / MCS: Physical / Mental Component Summary 


\section{TABLE 3: Reporting of constipation: comparison of people with Parkinson's and partner / carer (controls) from baseline questionnaires}

\begin{tabular}{|c|c|c|c|c|c|c|}
\hline \multirow[t]{2}{*}{ Item } & \multirow[t]{2}{*}{ Responses } & \multicolumn{2}{|c|}{$\begin{array}{c}\text { People with Parkinson's } \\
\text { (PwP) } \\
\text { n=121* }\end{array}$} & \multicolumn{2}{|c|}{$\begin{array}{c}\text { Partners /Carers } \\
\text { (Controls) } \\
\mathbf{n}=\mathbf{5 4 *} \\
\end{array}$} & \multirow{2}{*}{$\begin{array}{l}\text { Significant } \\
\text { difference } \\
\text { PwP vs } \\
\text { Controls }\end{array}$} \\
\hline & & $\mathbf{n}$ & $\%$ & $\mathbf{n}$ & $\%$ & \\
\hline \multirow{4}{*}{$\begin{array}{l}\text { How often do you } \\
\text { currently suffer } \\
\text { from constipation? }\end{array}$} & Always/v often & 32 & 26.5 & 1 & 1.9 & \multirow{4}{*}{$\begin{array}{l}\text { Always/very } \\
\text { often vs rest } \\
p=<.001\end{array}$} \\
\hline & Quite often & 19 & 15.7 & 2 & 3.7 & \\
\hline & Sometimes & 31 & 25.6 & 12 & 22.2 & \\
\hline & Never / rarely & 39 & 32.2 & 39 & 72.2 & \\
\hline \multirow{3}{*}{$\begin{array}{l}\text { To what extent is } \\
\text { constipation a } \\
\text { cause of concern? }\end{array}$} & A lot & 28 & 23.1 & 4 & 7.4 & \multirow{3}{*}{$\begin{array}{l}\text { A lot vs little, not } \\
\text { at all } \\
\mathrm{p}=.013\end{array}$} \\
\hline & A little & 43 & 35.5 & 5 & 9.3 & \\
\hline & Not at all & 50 & 41.3 & 45 & 83.3 & \\
\hline \multirow{4}{*}{$\begin{array}{l}\text { Over your adult } \\
\text { life, how often has } \\
\text { constipation been a } \\
\text { cause of concern? }\end{array}$} & Always/v often & 5 & 4.1 & 3 & 5.6 & \multirow{4}{*}{$\begin{array}{l}\text { Always, quite } \\
\text { often vs } \\
\text { sometimes, } \\
\text { never: } \mathrm{p}=.809\end{array}$} \\
\hline & Quite often & 10 & 8.3 & 3 & 5.6 & \\
\hline & Sometimes & 17 & 14.1 & 7 & 13.0 & \\
\hline & Never / rarely & 89 & 73.6 & 41 & 75.9 & \\
\hline $\begin{array}{l}\text { How often do you } \\
\text { open your bowels } \\
\text { on a typical day? }\end{array}$ & $\begin{array}{l}\text { Mean number of times } \\
\text { per day }\end{array}$ & $\begin{array}{c}0.96 \\
(n=120)\end{array}$ & $\begin{array}{l}\mathrm{SD}= \\
0.72\end{array}$ & $\begin{array}{c}1.36 \\
(n=52)\end{array}$ & $\begin{array}{l}\mathrm{SD}= \\
0.77\end{array}$ & $\mathrm{p}=.002$ \\
\hline \multirow{5}{*}{$\begin{array}{l}\text { Rome criterion: for } \\
\text { at least a quarter of } \\
\text { the time during the } \\
\text { last } 3 \text { months have } \\
\text { you had: }\end{array}$} & $\begin{array}{l}\text { to strain when opening } \\
\text { your bowels? Yes }\end{array}$ & $\begin{array}{c}84 \\
(n=120)\end{array}$ & 70.0 & $\begin{array}{c}13 \\
(n=52)\end{array}$ & 25.0 & $\mathrm{p}<.001$ \\
\hline & $\begin{array}{l}\text { lumpy or hard stools? } \\
\text { Yes }\end{array}$ & 78 & 64.5 & $\begin{array}{c}12 \\
(n=49)\end{array}$ & 24.5 & $\mathrm{p}<.001$ \\
\hline & $\begin{array}{l}\text { sensation of incomplete } \\
\text { evacuation? Yes }\end{array}$ & 67 & 55.4 & $\begin{array}{c}16 \\
(n=50)\end{array}$ & 32.0 & $\mathrm{p}=.005$ \\
\hline & $\begin{array}{l}2 \text { or fewer bowel } \\
\text { movements / week?Yes }\end{array}$ & $\begin{array}{c}32 \\
(n=120)\end{array}$ & 26.7 & $\begin{array}{c}3 \\
(n=49)\end{array}$ & 6.1 & $\mathrm{p}=.003$ \\
\hline & $\begin{array}{l}\text { Mean number of } \\
\text { symptoms. (Range 0-4) }\end{array}$ & $\begin{array}{c}2.17 \\
(n=119)\end{array}$ & $\begin{array}{l}\mathrm{SD}= \\
1.28\end{array}$ & $\begin{array}{c}0.88 \\
(n=49)\end{array}$ & $\begin{array}{l}\mathrm{SD}= \\
1.20\end{array}$ & $\mathrm{p}<.001$ \\
\hline $\begin{array}{l}\text { Constipated by } \\
\text { Rome criterion }\end{array}$ & Yes to $>=2$ symptoms & $\begin{array}{c}87 \\
(n=119)\end{array}$ & 73.1 & $\begin{array}{c}12 \\
(n=49)\end{array}$ & 24.5 & $\begin{array}{l}>=2 \text { vs }<2 \\
p<.001\end{array}$ \\
\hline $\begin{array}{l}\text { In the last } 7 \text { days, } \\
\text { have you taken: }\end{array}$ & $\begin{array}{l}\text { laxatives prescribed by } \\
\text { Doctor? [1] Yes }\end{array}$ & $\begin{array}{c}25 \\
(\mathrm{n}=120)\end{array}$ & 20.8 & 4 & 7.4 & $\begin{array}{l}\text { Yes vs No } \\
\mathrm{p}=.028\end{array}$ \\
\hline $\begin{array}{l}\text { In the last } 7 \text { days, } \\
\text { have you taken }\end{array}$ & $\begin{array}{l}\text { laxatives you bought } \\
\text { from a chemist?[2]Yes }\end{array}$ & $\begin{array}{c}24 \\
(\mathrm{n}=120)\end{array}$ & 20.0 & 4 & 7.4 & $\begin{array}{l}\text { Yes vs No } \\
p=.036\end{array}$ \\
\hline $\begin{array}{l}\text { In the last } 7 \text { days, } \\
\text { have you taken }\end{array}$ & $\begin{array}{l}\text { any laxatives? } \\
\text { Yes }\end{array}$ & $\begin{array}{c}42[3] \\
(n=119)\end{array}$ & 35.3 & $6[3]$ & 11.1 & $\begin{array}{l}\text { Yes vs No } \\
p=.001\end{array}$ \\
\hline \multirow{5}{*}{$\begin{array}{l}\text { In the last } 7 \text { days, } \\
\text { have you tried any } \\
\text { of the following } \\
\text { (self help) means } \\
\text { of dealing with } \\
\text { constipation? }\end{array}$} & $\begin{array}{l}\text { Increased fluid intake? } \\
\text { Yes }\end{array}$ & $\begin{array}{c}22 \\
(\mathrm{n}=119)\end{array}$ & 18.5 & $\begin{array}{c}4 \\
(n=46)\end{array}$ & 8.7 & $p=.122$ \\
\hline & $\begin{array}{l}\text { Increased fibre intake? } \\
\text { Yes }\end{array}$ & $\begin{array}{c}26 \\
(n=119)\end{array}$ & 21.9 & $\begin{array}{c}4 \\
(n=45)\end{array}$ & 8.9 & $\mathrm{p}=.055$ \\
\hline & $\begin{array}{l}\text { Increased exercise? } \\
\text { Yes }\end{array}$ & $\begin{array}{c}16 \\
(n=119)\end{array}$ & 13.5 & $\begin{array}{c}1 \\
(n=46)\end{array}$ & 2.2 & $\mathrm{p}=.033$ \\
\hline & $\begin{array}{l}\text { Eaten more fruit/ } \\
\text { vegetables? Yes }\end{array}$ & $\begin{array}{c}43 \\
(n=119)\end{array}$ & 36.1 & $\begin{array}{c}7 \\
(n=46)\end{array}$ & 15.2 & $\mathrm{p}=.009$ \\
\hline & $\begin{array}{l}\text { Eaten/ avoided certain } \\
\text { food? Yes }\end{array}$ & $\begin{array}{c}19 \\
(\mathrm{n}=118)\end{array}$ & 16.1 & $\begin{array}{c}2 \\
(n=45)\end{array}$ & 4.4 & $\mathrm{p}=.047$ \\
\hline $\begin{array}{l}\text { At least a quarter } \\
\text { of the time, do you }\end{array}$ & $\begin{array}{l}\text { have pain opening your } \\
\text { bowels? Yes }\end{array}$ & $\begin{array}{c}22 \\
(\mathrm{n}=120)\end{array}$ & 18.3 & $\begin{array}{c}6 \\
(n=48) \\
\end{array}$ & 12.5 & $\mathrm{p}=.359$ \\
\hline \multirow{3}{*}{$\begin{array}{l}\text { Do you use finger } \\
\text { to help empty } \\
\text { bowels? }\end{array}$} & Always/ Often & 4 & 3.4 & 1 & 1.7 & \multirow{3}{*}{$\begin{array}{l}\text { Always, often vs } \\
\text { sometimes, never } \\
\mathrm{p}=.606\end{array}$} \\
\hline & Sometimes & 8 & 6.6 & 0 & 0 & \\
\hline & Never / rarely & 109 & 90.1 & 53 & 98.3 & \\
\hline \multirow{3}{*}{$\begin{array}{l}\text { Do you get soiling } \\
\text { after opening your } \\
\text { bowels? }\end{array}$} & Always/ Often & 9 & 7.5 & 1 & 1.7 & \multirow{3}{*}{$\begin{array}{l}\text { Always, often vs } \\
\text { sometimes, never } \\
\mathrm{p}=.141\end{array}$} \\
\hline & Sometimes & 16 & 13.2 & 5 & 9.3 & \\
\hline & Never/ rarely & 96 & 79.3 & 48 & 88.9 & \\
\hline
\end{tabular}




\begin{tabular}{|l|l|c|c|c|c|l|}
\hline Do you wear & $\begin{array}{l}\text { protection for bowel } \\
\text { incontinence? Yes }\end{array}$ & 11 & 9.1 & 2 & 3.7 & $\mathrm{p}=.209$ \\
\hline $\begin{array}{l}\text { In the past 6 } \\
\text { months, have you }\end{array}$ & $\begin{array}{l}\text { had haemorrhoids } \\
\text { (piles) or bleeding from } \\
\text { back passage?[5] Yes }\end{array}$ & $\begin{array}{c}23 \\
(\mathrm{n}=118)\end{array}$ & 19.5 & $\begin{array}{c}12 \\
(\mathrm{n}=52)\end{array}$ & 23.1 & $\mathrm{p}=0.594$ \\
\cline { 2 - 6 } & $\begin{array}{l}\text { used suppositories for } \\
\text { constipation? Yes }\end{array}$ & $\begin{array}{c}12 \\
(\mathrm{n}=106)\end{array}$ & 11.3 & 2 & 6.3 & $\mathrm{p}=0.405$ \\
\cline { 2 - 6 } & $\begin{array}{l}\text { had an enema for } \\
\text { constipation? Yes }\end{array}$ & $\begin{array}{c}3 \\
(\mathrm{n}=103)\end{array}$ & 2.9 & $\begin{array}{c}1 \\
(\mathrm{n}=29)\end{array}$ & 3.5 & $\mathrm{p}$ large \\
\cline { 2 - 6 } & $\begin{array}{l}\text { used any CAM for } \\
\text { constipation? [4] Yes }\end{array}$ & $\begin{array}{c}4 \\
(\mathrm{n}=103)\end{array}$ & 3.9 & 3.6 & $\mathrm{p}$ large \\
\hline Have you ever & $\begin{array}{l}\text { been hospitalised for } \\
\text { constipation? Yes }\end{array}$ & $\begin{array}{c}5 \\
(\mathrm{n}=116)\end{array}$ & 4.3 & 1 & 1.9 & $\mathrm{p}=.419$ \\
\hline
\end{tabular}

Key: * Missing observations for some variables; SD: Standard Deviation

Notes: [1] Prescribed laxatives mentioned: Movicol, senna, dioctyl, manevec, fybogel, lactulose

[2] Laxatives reported purchased 'over-the-counter': senna, fybogel, lactulose, exlax, fruit cubes, dulcolax, syrup of figs, Epsom salts, ortisan

[3] Of the 42 people with Parkinson's (6 controls) who took any laxative, 6 (2) took both prescribed and laxatives purchased from chemist

[4] CAMs (Complementary or Alternative Medicine) reported: ortisan, reiki

[5] Any reports of bleeding were referred to the doctor 
TABLE 4: Associations between measures of constipation in the baseline questionnaires

\begin{tabular}{|l|c|c|c|c|}
\hline \multirow{2}{*}{ Measures of constipation } & \multicolumn{2}{|c|}{ Patients } & \multicolumn{2}{c|}{ Carers } \\
\cline { 2 - 5 } & Odds ratio & $\mathbf{9 5 \%}$ CI & Odds ratio & 95\% CI \\
\hline Now of concern vs Rome & 13.95 & 1.74 to 112.13 & $7.20^{*}$ & 0.56 to 92.37 \\
\hline Now of concern v any laxative & 8.26 & 3.02 to 22.60 & 11.50 & 1.21 to 109.69 \\
\hline Now of concern v any self help & $1.97 *$ & 0.80 to 4.81 & $11.67 *$ & 0.86 to 157.70 \\
\hline Rome v any laxative & 12.72 & 2.77 to 58.39 & $5.83^{*}$ & 0.80 to 39.24 \\
\hline Rome v any self help & 3.49 & 1.41 to 8.64 & 22.50 & 3.20 to 158.05 \\
\hline Any laxative v any self help & 2.59 & 1.16 to 5.81 & $11.67^{*}$ & 0.86 to 157.70 \\
\hline
\end{tabular}

Key: * Not significant

Notes: Subjective measure: Constipation is currently a cause for concern (a lot vs not a lot )

Objective measure: Meets Rome criterion (reports $>=2$ symptoms)

Behavioural measures: in the last 7 days, taken any laxative; taken any self help measure 
TABLE 5: Bowel activity reporting: comparison of people with Parkinson's and partner / carer (controls) from 28 day diaries.

\begin{tabular}{|c|c|c|c|c|c|c|c|c|c|c|c|}
\hline & \multicolumn{5}{|c|}{$\begin{array}{c}\text { People with Parkinson's } \\
(P w P) n=106 *\end{array}$} & \multicolumn{5}{|c|}{$\begin{array}{l}\text { Partner / Carer } \\
\text { (Controls) } n=43 *\end{array}$} & \multirow{2}{*}{$\begin{array}{c}\text { Significant } \\
\text { difference } \\
\text { PwP vsControls }\end{array}$} \\
\hline & Mean & SD & Min. & Median & Max. & Mean & SD & Min. & Median & Max. & \\
\hline $\begin{array}{l}\text { Mean number of bowe } \\
\text { movements / day }\end{array}$ & .95 & .41 & .21 & .92 & 2.4 & 1.19 & .42 & .5 & 1.07 & 2.75 & $\mathrm{p}=.003$ \\
\hline $\begin{array}{l}\text { Mean strain level } \\
(0 \text { none }-3 \text { severe })\end{array}$ & .94 & .63 & 0 & .93 & 2.7 & .39 & .43 & 0 & .23 & 1.4 & $\mathrm{p}<.001$ \\
\hline $\begin{array}{l}\text { \% bowel movements } \\
\text { with straining }\end{array}$ & 62.0 & 33.6 & 0 & 79.3 & 100 & 30.9 & 30.4 & 0 & 23.3 & 100 & $\mathrm{p}<.001$ \\
\hline $\begin{array}{l}\text { Mean consistency }(1 \\
\text { very hard }-7 \text { liquid })^{\$}\end{array}$ & 3.4 & 1.1 & .5 & 3.4 & 5.7 & 3.7 & .74 & 2.0 & 3.7 & 5.9 & $\mathrm{p}=.034$ \\
\hline $\begin{array}{l}\% \text { bowel movements } \\
\text { hard stools }(1,2)^{\$}\end{array}$ & 26.6 & 31.0 & 0 & 11.6 & 100 & 11.3 & 18.2 & 0 & 5.9 & 92.3 & $\mathrm{p}<.001$ \\
\hline $\begin{array}{l}\text { \% bowel movements } \\
\text { soft stools }(6,7)^{\S}\end{array}$ & 7.2 & 15.0 & 0 & 0 & 87.5 & 4.4 & 10.1 & 0 & 0 & 55.1 & $\mathrm{p}=.18$ \\
\hline $\begin{array}{l}\text { \% bowel movements } \\
\text { not felt empty }\end{array}$ & 35.7 & 33.2 & 0 & 26.6 & 100 & 12.3 & 16.8 & 0 & 7.1 & 83.3 & $\mathrm{p}<.001$ \\
\hline $\begin{array}{l}\text { Mean time spent } \\
\text { (minutes) }\end{array}$ & 3.7 & 3.8 & .12 & 2.6 & 25.8 & 2.1 & 2.4 & .16 & 1.2 & 11.1 & $\mathrm{p}=.002$ \\
\hline $\begin{array}{l}\text { \% of days laxatives } \\
\text { taken }\end{array}$ & 13.4 & 27.5 & 0 & 0 & 100 & 2.5 & 14.3 & 0 & 0 & 92.9 & $\mathrm{p}=.002$ \\
\hline $\begin{array}{l}\% \text { of days use self } \\
\text { help measure }\end{array}$ & 2.3 & 9.6 & 0 & 0 & 75.0 & 0 & 0 & 0 & 0 & 0 & \\
\hline $\begin{array}{l}\text { Meet Rome criterion } \\
\text { for constipation\# }\end{array}$ & $\mathrm{n}=37$ & $34.9 \%$ & & & & $\mathrm{n}=3$ & $.0 \%)$ & & & & $\mathrm{p}<.001$ \\
\hline
\end{tabular}

* There was minimal missing information. Most participants completed the full 28 days of record keeping (people with Parkinson's: mean 25.8 days; SD 4.5; median 28; range 2 - 30; partners / carers: mean 27.2 days; SD 1.8; median 28; range 20 - 28).

\$ From Bristol Stool Form Chart [21]

\# To meet the Rome criterion: for at least a quarter of the time any two of the following symptoms must be present: straining when opening bowels (defined as a mean straining score $>1$ from diary entries); lumpy or hard stools (mean Bristol stool score $<3$ ); sensation of incomplete evacuation (report not feeling bowels empty $>$ $33 \%$ of bowel movements); $<3$ bowel movements per week (mean of $<3 / 7=0.43$ ). 